\title{
Parenting Styles in Dealing with Children's Online Gaming Routines
}

Muhamad Uyun, Universitas Islam Negeri Raden Fatah Palembang, Indonesia,
muhamaduyun_uin@radenfatah.ac.id Orcid: 0000-0002-6561-7437

Mirzon Daheri, Institut Agama Islam Negeri (IAIN) Curup, Indonesia, mirzondaheri@iaincurup.ac.id Orcid: 0000-0002-9627-2873

Sutarto, Institut Agama Islam Negeri (IAIN) Curup, Indonesia, sutarto@iaincurup.ac.id Orcid: 0000-00015386-1558

Fuad Nashori, Universitas Islam Indonesia (UII) Yogyakarta, Indonesia, fuadnashori@uii.ac.id Orcid: 00000001-7826-3386

*Idi Warsah, Institut Agama Islam Negeri (IAIN) Curup, Indonesia, idiwarsah@gmail.com Orcid: 00000002-9406-1415

Ruly Morganna, Institut Agama Islam Negeri (IAIN) Curup, Indonesia, rulymorganna@gmail.com Orcid: 0000-0002-2188-2511

Corresponding Author

\begin{abstract}
Many studies on the issues of parenting styles and children's gaming routines have been undertaken quantitatively but not qualitatively. Thus, the present study aimed at qualitatively investigating the parenting styles in dealing with children's routines of playing online games via gadgets. 20 parents and 10 children in Uram Jaya sub-district, Lebong regency, Bengkulu, Indonesia were involved as the participants. The data were garnered from interviews and observations. This study revealed that the parents applied authoritarian, authoritative, and permissive parenting styles in dealing with children's gaming routines. The permissive parenting style seemed to contribute to children's gaming addiction because the children, receiving this parenting style from one of their parents, played online games in the span of 2.5 and 4 hours. Subsequently, the authoritarian and authoritative parenting styles seemed to be able to control children's gaming routines. Nevertheless, the authoritarian parenting style did not seem good at controlling children's psychosocial development.
\end{abstract}

Keywords: Parenting styles, gaming routines, gaming addiction Received: 07.12.2020 Accepted: 21.01.2021

Published: 04.02.2021

\section{INTRODUCTION}

Today's children are often called digital native generations (Nelissen \& Bulck, 2017). The foregoing is a term for those who were born in the digital era or who were born after 2000. Even though this actually dates back to 1980 since the digital revolution, after 2000, the ease of connectivity among people over the world has increasingly become a feature of digital era. The Internet makes communication easier regardless of how far the distance is between the communicator and communicant. In such a way, globalization becomes an inevitable thing. This is the condition experienced by digital native generations.

The emergence of gadgets or smartphones also makes communication, connection, and flexibility easier and easier. So much information can be accessed through gadgets. However, there are also challenges that digital native generations must face such as the invasions of new values, life styles, and economic competition (Hong et al., 2019) as well as the exposures to new, diverse cultures triggering perspective and interpersonal conflicts (Morganna et al., 2020; Warsah, 2020b, 2020a; Warsah et al., $2019,2021)$. Another thing which is also a challenge for digital native generations especially children is that the amount of time they spend sitting and holding gadgets will create problems in various aspects of life especially if they have been addicted to using gadgets. Many of today's children are addicted to using gadgets for playing online games. In so doing, children will get some disadvantages. Physically, they will experience decreases in visual function and physical endurance since their bodies do not move ideally. However, it is unique because some argued that the foregoing claim is not necessarily true since online gaming has now been determined to be categorized as a sport called e-sport (Jenny et al., 2016; Llorens, 2017). The players are expected to be physically fit and have adequate nutrition. Nevertheless, online gaming can be an e-sport if it is done in a controlled way. It is going to end up with many disadvantages if children play online games via gadgets without control. 
Also, children who are exposed to the internet too much can experience internet risks (Chu, 2015). Internet risks are related to many things that have the potential to cause problems such as exposures to sexual contents, meeting dangerous people, racism, commercial manipulation, and so on (Chang et al., 2016). Another worrying effect is that children will suffer from an internet addiction disorder (IAD), or for gamers they will likely suffer from a mental or psychological disorder (Iacolino et al., 2019). This has happened to many teenagers and children such as being anxious and thinking about games all the time until they get angry if they are not allowed to play games. Addiction to playing games can weaken children's social competences (Zamani et al., 2010). It is not to mention that gaming can affect children's learning responsibilities. Quantitative research on adolescents in Banjarmasin showed that the higher the adolescents' intensity of playing games is, the lower their learning motivation will be (Husna et al., 2017). Thus, it is not surprising that in the 11th International Classified Disease, WHO categorizes this as a gaming disorder. The indication is a significant decrease in the values of personality, family, social, education, and other important functions (WHO, 2018). It means that addiction to games has an impact on various sides of one's life.

Children's addiction to games causes many concerns among parents. In this regard, Parents' styles of parenting play an important role in guiding and controlling children in terms of playing games. Parenting styles refer to parents' ways to guide and educate children in the circle of familial interactions. There are three parenting styles that are commonly classified by experts, namely authoritarian, authoritative, and permissive parenting styles (Aloia \& Warren, 2019; Baumrind, 1991; Huver et al., 2007; Luo et al., 2019; Paulussen-hoogeboom \& Stams, 2008). The first is authoritarian parenting style. It is associated with strict rules, strict monitoring, and less attention to children's psychology (Baumrind, 1991; Huver et al., 2007; Paulussen-hoogeboom \& Stams, 2008). Treated by this parenting style, children must comply with all strict rules that parents set (King et al., 2016; Uji et al., 2014). Research conducted by Georgiou et al. (2013) showed that this parenting style tends to have an impact on bullying against children. The authoritarian parenting style can also make children suffer from anxiety (Cheung et al., 2014; Muñoz et al., 2017). The second is an authoritative parenting style. It is a well-controlled style of parenting (Lau \& Power, 2019), and it establishes good and open communication with children (Ren et al., 2019). This parenting style provides children with adequate supports and good psychological care (Huver et al., 2007; Lu \& Chang, 2013; Paulussen-hoogeboom \& Stams, 2008; Stephenson et al., 2009; Yu et al., 2015). This parenting style has a positive impact on children's social development (Ren et al., 2019; Yu et al., 2015), and it is also effective in guiding children to be cooperative individuals (Miguel et al., 2016; Takeuchi \& Takeuchi, 2008). The third is permissive parenting style. It describes the condition of parents who tend to allow children to do whatever they like with less control (Barton \& Hirsch, 2016; Baumrind, 1991; Huver et al., 2007; Paulussen-hoogeboom \& Stams, 2008; Uji et al., 2014). This style of parenting is prone to making children undisciplined and leads them to have low emotional control (Baumrind, 1991; Shumow et al., 1998; Tu et al., 2018; Wischerth et al., 2016).

With their various types, parenting styles will provide different ways of dealing with children who play games via gadgets routinely. Studies related to parenting styles have often been conducted. Konok et al. (2019) conducted a survey to Hungarian parents concerning their children's activities in using mobile phones. Their study revealed that the permissive parenting style has an impact on the high intensity of mobile phone use amid children. Maftei and Enea (2020) examined an issue associated with internet gaming disorder among adolescents and children. Their study revealed that the children who receive permissive parenting style treatments tend to suffer from Internet gaming disorder. Furthermore, Kveton and Jelinek (2016) examined parenting styles and children's gaming addiction. Their study shows that inconsistent parenting styles lead to high levels of addiction to video-gaming. On average, many studies on parenting styles and gaming are undertaken in quantitative ways. Conducting qualitative studies on these issues is worth doing to uncover the related data in depth as comparable views to balance the common quantitative data. Thus, the presentations of data in the literature related to parenting styles and gaming issues can be balanced in the aspects of both quantitative and qualitative data.

Regarding parenting styles and gaming issues, a preliminary study conducted by the researchers in the sub-district of Uram Jaya, Lebong regency, Bengkulu, Indonesia found that children have the routines of playing online games via gadgets every day, especially for those at the ages of 7-13 years old. This phenomenon is unique because Uram Jaya is a small sub-district where the average population works as farmers. The literacy competence of children in this sub-district does not also look better than that of children in the neighboring sub-districts. However, children's routines of playing online games via gadgets run every day with varied durations. This phenomenon encourages the researchers to investigate the parents' styles of parenting in dealing with children who have the routines of playing online games via gadgets in a qualitative way. This phenomenon is worrying because such gaming, if not properly controlled, can make children suffer from game addiction (Linda et al., 2016) as well as internet gaming 
disorder (Maftei \& Enea, 2020). This investigation is also aimed at fulfilling the literature gap by providing scientific findings from a qualitative viewpoint. Thus, the present study is conducted resting upon the following research questions: 1) What are the parenting styles applied by parents in dealing with children who have the routines of playing online games via gadgets? 2) How are children's gaming conditions controlled by their parents' styles of parenting?

\section{METHODS}

This study applied a qualitative approach in a way of phenomenological method (Ary et al., 2010; Creswell, 2007) with the aims of revealing the parents' styles of parenting in dealing with children's routines of playing online games via gadgets and investigating children's gaming conditions controlled by their parents' styles of parenting. The rationale for choosing a qualitative approach in this regard was because this study sought to investigate the detailed and in-depth data with respect to parenting styles in dealing with children's routines of playing online games. The qualitative approach was regarded as the most ideal one to be adopted for the sake of revealing the data of this study. This study was conducted in a sub-district in Bengkulu, Indonesia. This sub-district is known as Uram Jaya. Based on the preliminary study, elementary school children especially those that aged from 7 to 13 years old seemed to have the routines of playing online games via their gadgets every day. Besides, they already had their own gadgets to play online games. It seemed that their parents bought them gadgets.

\section{Participants}

20 parents and 10 elementary school children that aged between 7 and 13 years old were involved as the participants of this study. They were selected as the participants by means of a purposive sampling technique (Fraenkel et al., 2012) which assigned several selection criteria. For parent participants, the selected parents were those who had children still studying at elementary schools. For children participants, they were elementary school children at the ages between 7 and 13 years old; they had their own gadgets as the media to play online games; and they had routines of playing games through their gadgets every day. Individuals who met these criteria were recruited as the participants.

\section{Data Collection Techniques}

The data of the present study were taken from interviews and observations. In-depth interviews were conducted in order to garner detailed data. Observations were made in a way of unstructured observations wherein the observational data were recorded using a video recorder and field notes. The data related to parenting styles were revealed by interviews and observations. Furthermore, the data corresponding to children's routines of playing online games via gadgets were gathered from observations. This study deliberately made use of more than one technique of data collection as a triangulation method in order that this study could obtain credible data and avoid any bias.

\section{Data Analysis Technique}

The data of the present study were analyzed using an interactive model of analysis as proposed by Miles et al. (2014). This analysis model had four essential elements which subsumed data collection, data condensation, data display, and conclusion drawing. For data collection, as previously explained, the data were collected using interview and observation techniques that were assigned to answer the formulated research questions. For data condensation, the data were condensed by classifying them based on some meaningful themes that emerged and represented the data contents. The data which were grouped pursuant to the representative themes were then presented in the form of tabulated data and detailed explanations. The explanations consisted of the presentations of some selected interview transcripts, data interpretation, and data discussion. For conclusion drawing, the data were summarized in a meaningful and representative manner.

\section{RESULTS}

\section{Parenting Styles}

Parenting style is a variation of relationship model between parents and children in assisting children's psycho-social development (Smith et al., 2016; Vučković et al., 2020). This study was begun by conducting interviews with 20 parents in Uram Jaya sub-district, Lebong regency, Bengkulu, Indonesia. They were a married couple from 10 families. The results of interviews indicated that they applied three types of parenting styles in dealing with their children's routines of playing online games via gadgets. These types included authoritative, authoritarian, and permissive parenting styles. The following table 1 presents the 
summary of interview data followed by detailed explanations along with some samples of interview transcripts selected to represent the overall data.

Table 1. Parents' Conditions and Their Parenting Styles

\begin{tabular}{|c|c|c|c|c|}
\hline Parents & Education & Age & Job & Parenting Styles \\
\hline Father 1 & Senior High School & 39 & Ojek's rider & Authoritative \\
\hline Mother 1 & Elementary School & 37 & Housewife & Authoritative \\
\hline Father 2 & Senior High School & 41 & Trader & Authoritarian \\
\hline Mother 2 & Junior High School & 37 & Housewife & Authoritative \\
\hline Father 3 & Undergraduate & 39 & Governmental Official & Authoritative \\
\hline Mother 3 & Senior High School & 38 & Entrepreneur & Permissive \\
\hline Father 4 & Senior High School & 37 & Farmer & Authoritative \\
\hline Mother 4 & Senior High School & 34 & Farmer & Authoritarian \\
\hline Father 5 & Senior High School & 35 & Governmental Official & Authoritarian \\
\hline Mother 5 & Senior High School & 35 & Trader & Permissive \\
\hline Father 6 & Senior High School & 38 & Farmer & Authoritarian \\
\hline Mother 6 & Senior High School & 34 & Employee & Authoritative \\
\hline Father 7 & Senior High School & 36 & Farmer & Permissive \\
\hline Mother 7 & Junior High School & 35 & Farmer & Authoritative \\
\hline Father 8 & Junior High School & 43 & Farmer & Authoritarian \\
\hline Mother 8 & Elementary School & 39 & Farmer & Authoritarian \\
\hline Father 9 & Senior High School & 36 & Entrepreneur & Authoritative \\
\hline Mother 9 & Undergraduate & 34 & Trader & Authoritative \\
\hline $\begin{array}{l}\text { Father } \\
10\end{array}$ & Senior High School & 42 & Farmer & Authoritative \\
\hline $\begin{array}{l}\text { Mother } \\
10\end{array}$ & Senior High School & 36 & Governmental Official & Authoritative \\
\hline
\end{tabular}

\section{Authoritarian parenting style}

Based on the results of interviews, it seemed that the parents applied diverse parenting styles, and to some extent different parenting styles were also found between fathers and mothers. From interviews with 20 parents, it was encountered that 6 parents applied an authoritarian parenting style. The following transcripts of interviews were deliberately selected from the raw data to represent the entire data portraying the authoritarian parenting style.

I try to make my son disciplined at home by scolding him for taking too much time to play games with his gadget. As a father, I hope that my son can help his mother at home when I am leaving home to trade. I am very worried that my son's learning quality at school will decrease just because he plays games too often (Father 2).

We are a farming family. I give strict rules to my child to study hard and not to play a lot, let alone playing online games with his gadget. I think gadget is functional for learning, not for playing games (Mother 4).

I am a teacher. For me, my child must be disciplined, and I told him to study hard and not to play games on his gadget (Father 5 ).

I gave a schedule to my child so that she has a responsibility to help me in the field once she comes home from school (Father 6).

My wife and I don't like it when our child plays games with her gadget too much. We give her a gadget as a media of learning but not as a media of playing games (Father 8).

From a range of interview transcripts above, it could be seen that the parenting style used by the 6 parents was categorized as authoritarian because they tended to impose strict rules on their children. They scolded their children for taking too much time to play online games on their gadgets, gave strict rules for their children in order to be disciplined, gave their children schedules to help them work, and tended not to allow their children to play games. 


\section{Authoritative parenting style}

Interview data also showed that there were 11 parents who applied the parenting style categorized as an authoritative parenting style. These data are demonstrated by the following interview transcripts purposefully selected to represent all raw data addressing things related to the authoritative parenting style.

I work as an Ojek's rider, and I have enough time to communicate with my child. I never forbid my child to play online games as long as he can manage his time for when to study and when to play (Father 1).

I always control my child daily. I don't scold him for playing online games via his gadget, but I always remind him of not playing games too much. I think, playing games is one of my child's needs especially at his current age (Mother 1).

Even though my husband often gives strict rules to my child not to play online games, I feel sorry for him, and I give him permission to play online games. In my opinion, there is no any relationship between playing games on his gadget and his learning quality at school as long as the portion can be managed properly (Mother 2).

As far as I am concerned, my wife tends to allow my son to play online games continuously. For me, playing online games is okay as long as he can manage his time for when to study and when to play games. I try to communicate well with my child about this case (Father 3).

My wife seems to get quite tough with my kid especially when he wants to play online games. My wife prefers my kid to help us work in the field. For me, I prefer that my kid gets his free time to play and learn. For anything as regards working in the field, I think, my wife and I can handle it (Father 4).

I am quite open with my child. I allow her to play online games as long as it doesn't take too much time. I will always monitor and remind her gently of doing her homework (Mother 6).

I understand that my daughter should be able to learn to manage her own time. I guide her to be able to make a kind of daily schedule so that she has her own time to play games and to learn. I think, playing games will not damage my daughter's achievement at school as long as the composition of time division is well-managed (Mother 7).

I think, playing games is one of the needs of today's children. I really understand that. The important thing is that we, parents, always guide children to be aware of time management (Father 9).

I agree with my husband that the most important thing is that we consistently strive to guide our child to be aware of the importance of time control. In my opinion, even in some of the games that my child plays, there is some input which can train his intellectual thinking. So, games are not always negative (Mother 9).

I don't want to scold my daughter just because she likes playing games. I can still control and help her understand that there is a certain time to play games, and there is also a particular time to learn or deal with scholastic matters. I can guide my daughter without having to be hard on her (Father 10). We love our child. We will guide her according to her needs. I really understand that she needs time to play and learn. Playing games will not negatively affect her school as long as we can help guide her (Mother 10).

The interview data above illustrate the authoritative attitude of parents in dealing with their children playing online games via gadgets. Based on the authoritative parenting style applied by parents, the parents built attitudes such as establishing good communication with children, appreciating that playing games is one of the children's needs but still controlling children's routines of playing games, guiding children to manage their time for when to play online games and when to learn, allowing children to play games with a reasonable time, and not being harsh on children.

\section{Permissive parenting style}

The interview data also exhibited that there were three parents that seemed to have applied the permissive parenting style in dealing with children's routines of playing online games via their gadgets. This can be seen in the following interview transcripts deliberately chosen to represent all raw data whose contents are pertinent to the permissive parenting style.

I really love my son. He is my only child. So, I give him a gadget to play games as he wants. The important thing for me is that my child is happy (Mother 3).

I can't bear to find my son crying if he is not allowed to play games. Every child needs to have time to play games. The important thing is that my child continues to go to school in a way that other children in general do (Mother 5).

I have never stopped my child from playing games. I am actually happy to see that my child is always cheerful (Father 7). 
The interview data above illustrate the style of permissive parenting because parents seemed to have less-control over children, and they seemed to just allow children to do what they wanted such as playing games without any guiding role that could make them aware of the importance of time management. Permissive parents also seemed to give everything that their children asked for. They held a principle that the important thing for them was that their children could be happy. Thus, they allowed their children to play games freely.

The data garnered from interviews were also aligned with those obtained from observations. Observational data confirmed that there were variations in parenting styles that the parents applied in dealing with their children's routines of playing games, and even at some point a couple of parents, father and mother, were found to have applied diverse parenting styles. Observational data showed that authoritarian parents tended to have many demands. They would give lengthy comments about the things they hoped their child would do. They would be tough verbally, and they were sometimes even hard on their children by giving them physical punishment if the children broke the familial rules. Authoritarian parents held the perspective that playing games would have a negative impact on children's learning quality at schools. However, for children, this parenting style was perceived too fussy. Parents did not really pay attention to their children's perspectives. Parents tended to decide everything merely based on their experiences or knowledge. The data in this regard were unique because the authoritarian parenting style was applied not only by parents with low educational backgrounds but also by those with secondary educational backgrounds.

In contrast to the authoritative parenting style, even though parents demanded that their children did some familial rules, the parents still maintained communication, dialogues, and efforts to understand their children. The rules were set together between children and parents. In this way of parenting, parents' care and affection could be felt and understood by children. Children found it easier to fulfill their parents' wishes or suggestions. Children were more convinced that their parents actually wanted all good things for them. The observational data also showed that with the application of authoritative parenting style, the quantity of togetherness between parents and children was also relatively good. Togetherness was realized in various forms such as watching TV, eating, and playing together as well as talking about various things in an open way. Parents with an authoritative parenting style had the perspective that playing games would not adversely have an impact on children's learning quality at schools as long as children were guided well for the sake of being aware about the importance of time management.

Observational data also confirmed that a few parents applied the permissive parenting style. This parenting style seemed to be applied by parents because they were busy. One of the fathers adopted the permissive parenting style because he worked as a garden farmer. His time with family was very little. He mostly stayed in the garden. When coming home, his communication with his child was also not warmly established. It was not much different from a permissive mother. She had a business as a rice distributor. She often traveled to run her business such as to buy rice from farmers and bring it to traders outside the town. Meanwhile, the child was left with his grandmother. In the aforesaid two cases, the parents always looked tired of working after they came home. For mother 3, although she oftentimes stayed at home, she was mostly very busy with sewing clothes since she was a tailor. She gave her child a gadget and let her child be free to operate the gadget at any time the child wanted to. Parents with the permissive parenting style held a perspective that the most important thing was to fulfill their children's demands and needs such as one of which was to play online games via gadgets as much time as their children wanted to.

\section{Children's Routines of Playing Online Games via Gadgets}

Information regarding the conditions of children routines of playing online games via gadgets was collected through observations. The summary of observational data could be viewed from the presentation in table 2 below.

Table 2. Children's Contexts and Their Routines of Playing Online Games via Gadgets

\begin{tabular}{|l|l|l|l|}
\hline Children & Age & Education & Gaming hours per day \\
\hline Child 1 & 9 & 3rd grade of elementary school & 2 hours \\
\hline Child 2 & 10 & 4th grade of elementary school & 1 hour \\
\hline Child 3 & 11 & 5th grade of elementary school & 3 hours \\
\hline Child 4 & 7 & 1st grade of elementary school & 1 hour \\
\hline Child 5 & 7 & 1st grade of elementary school & 4 hours \\
\hline Child 6 & 10 & 4th grade of elementary school & 1 hour \\
\hline Child 7 & 8 & 2nd grade of elementary school & 2.5 hours \\
\hline
\end{tabular}




\begin{tabular}{|l|l|l|l|}
\hline Child 8 & 9 & 3rd grade of elementary school & 1 hour \\
\hline Child 9 & 8 & 2nd grade of elementary school & 1 hour \\
\hline Child 10 & 10 & 4th grade of elementary school & 2 hours \\
\hline
\end{tabular}

Table 2 exhibits that 7 out of 10 children had the routines of playing online games via gadgets in reasonable spans of time. Such time spans were considered normal because they were less than 2.5 hours. However, three children were regarded as playing games over the time threshold, or they were categorized as using gadgets excessively to play online games. Children 3 and 5 had the routines of playing online games after school within the spans of 3 and 4 hours respectively every day. Meanwhile, child 7 routinely used her gadget in the span of 2.5 hours or from 4:00 p.m. to 6:30 p.m. after school every day. However, this was still classified into an overtime category. If grounded in the parenting styles applied by the fathers and mothers, child 3 had an authoritative father and a permissive mother. Child 5 had an authoritarian father and a permissive mother. Furthermore, child 7 got a permissive father and an authoritative mother. Looking at this condition, it could be seen that there was a consistent similarity in the case of the application of permissive parenting style in terms of dealing with children's excessive gaming routines. However, the permissive parenting style was not found to have been adopted by both father and mother in one family. The forgoing means that the permissive parenting style was only applied by one of the parents from each of the three children. The permissive parenting style seemed to greatly influence children's weak competence in terms of time management for playing games via gadgets. However, the observational data confirmed that albeit being permissive, the parents still gave cautions to their children for the sake of avoiding any pornographic input. Occasionally, they kept checking their children's gadgets to ensure that their children were not exposed to pornographic contents.

Furthermore, seven children fell into the category of normal gadget users. Some of them received the authoritative parenting style, and the rest got the authoritarian parenting style. There were two children, children 1 and 10, who received the authoritative parenting style from their fathers and mothers, and those children almost fell into the category of gadget overuse. However, in general, the observational data in this aspect demonstrated that parents had good awareness of controlling their children's routines of playing online games via gadgets. The observational data also indicated that the authoritarian parenting style could control children's gaming routines. However, such a style of parenting was not considered good since it could negatively affect children's psychological and social competences.

\section{DISCUSSION AND CONCLUSIONS}

The current study revealed that there were three parenting styles adopted by 20 parents as the participants of this study, namely authoritarian, authoritative, and permissive parenting styles. This study also demonstrated that some fathers and mothers did not have the same parenting styles. Based on the results of interviews and observations, parents who applied the authoritarian parenting style tended to scold their children if they took too much time to play online games via gadgets, gave strict rules for children in order to be disciplined, provided schedules for children to help parents at work, and did not actually want their children to play online games. This set of data is in line with Baumrind (1991); Huver et al. (2007); and Paulussen-hoogeboom and Stams (2008) suggesting that authoritarian parents tend to give children strict rules. Such strict rules are usually caused by the authoritarian parents' expectation that their children must comply with all the details of familial rules applied (King et al., 2016; Uji et al., 2014). Furthermore, based on the data of this study, parents with the authoritative parenting style tended to establish good communication with their children. They seemed to appreciate that playing games was one of their children's needs, and they could also still control their children's routines of playing online games, guide children to manage their time for when to play games and when to learn, allow children to play games with a reasonable time span, and treat children well without being harsh. This set of data is aligned with Ren et al. (2019); and Takeuchi and Takeuchi (2008) who explained that parents who adopt an authoritative parenting style will guide children to be cooperative through establishing good communication. Authoritative parenting styles will guide children in a controlled pattern and support the development of children's emotional, social, and behavioral aspects (Lau \& Power, 2019; Yu et al., 2015). The data of this study subsequently showed that parents who applied the permissive style of parenting tended to give everything their children asked for, and they held a principle that the important thing was that their children could be happy. In so doing, they allowed their children to play online games via gadgets as much time as their children wanted to. This set of data is supported by Barton and Hirsch (2016) who said that parents who apply a permissive parenting style do not control their children's behavior. Such parents tend not to scold their children even when the children's behavior is not going normal (Uji et al., 2014). 
Regarding information about children's routines of playing online games via gadgets, the observational data of the present study revealed that out of 10 children, it seemed that 3 children had gaming routines that exceeded the normal range of time. They played online games in the span of time from 2.5 to 4 hours. Meanwhile, 7 children played games for less than 2.5 hours. The foregoing was categorized as normal. This information is confirmed by Putri (2018) stating that those categorized as having game addiction are ones who play more than 2.5 hours per day regardless of the intensity and interval of playing games. According to Linda et al. (2016), game addiction can decrease children's potential. For the three children who fell into a game-addiction category, they received the permissive parenting style from one of their parents. This finding is in line with a study conducted by Maftei and Enea (2020) uncovering that the permissive parenting style contributes to Internet gaming disorder which correlates with addiction to playing games. The data of this study also implied that the authoritarian and authoritative parenting styles contributed to a good control of children's gaming routines. This condition is also aligned with the findings revealed by Konok et al. (2019) demonstrating that the authoritative and authoritarian parenting styles can properly control children's use of gadgets.

As a conclusion, parents in Uram Jaya sub-district that are involved as the participants of the current study apply three parenting styles, namely authoritarian, authoritative, and permissive parenting styles. Parenting styles seem to have a role in dealing with children's routines of playing online games via gadgets. The permissive parenting style seems to be the least to give contribution to controlling children's gaming routines because this parenting style tends to give everything children ask for, and parents with a permissive parenting style hold a principle that the important thing is that their children can be happy. In such a way, they allow children to play online games via gadgets as the children want to. Furthermore, the authoritative and authoritarian parenting styles seem to have a good control over children's routines of playing online games. This is because the parents who apply the authoritative parenting style tend to build good communication with their children, appreciate that playing games is one of their children's needs and at the same time still control their children's routines of playing games, guide their children so that they can manage their time for when to play games and when to learn, allow their children to play games at a reasonable span of time, and avoid being harsh to their children. Furthermore, children who receive the authoritarian parenting style also do not suffer from gaming addiction because the parents tend to scold their children if they take too much time to play games via gadgets, give strict rules to their children in order to be disciplined, provide schedules for their children to help them at work, and do not actually expect their children to play online games. However, although the authoritarian parenting style seems to have a good effect on controlling children's gaming routines, this parenting style is not good for children's psychosocial development.

\section{CONFLICT OF INTEREST}

There is no conflict of interest regarding this article

\section{REFERENCES}

Aloia, L. S., \& Warren, R. (2019). Quality parent-child relationships: The role of parenting style and online relational maintenance behaviors. Communication Reports, 0(00), 1-14. https://doi.org/10.1080/08934215.2019.1582682

Ary, D., Jacobs, L. C., Sorensen, C. K., Walker, D. A., \& Razavieh, A. (2010). Introduction to research in education. In Measurement (8th ed., Vol. 4, Issue 43). Wadsworth, Cengage Learning. https://doi.org/10.1017/CB09781107415324.004

Barton, A. L., \& Hirsch, J. K. (2016). Permissive parenting and mental health in college students: Mediating effects of academic entitlement. Journal of American College Health, 64(1), 1-8. https://doi.org/10.1080/07448481.2015.1060597

Baumrind, D. (1991). The influence of parenting style on adolescent competence and substance use. Journal of Early Adolescence, 11(1), 59-95.

Chang, F.-C., Miao, N.-F., Chiu, C.-H., Chen, P.-H., Lee, C.-M., Chiang, J.-T., \& Chuang, H.-Y. (2016). Urbanrural differences in parental Internet mediation and adolescents' Internet risks in Taiwan. Health, Risk \& Society, 18(3-4), 188-204. https://doi.org/10.1080/13698575.2016.1190002

Cheung, C. K., Cheung, H. Y., \& Wu, J. (2014). Career unreadiness in relation to anxiety and authoritarian parenting among undergraduates. International Journal of Adolescence and Youth, 19(3), 336-349. https://doi.org/10.1080/02673843.2014.928784

Chu, D. (2015). Internet risks and expert views: a case study of the insider perspectives of youth workers in Hong Kong. Information, Communication \& Society, 1-18. 
https://doi.org/10.1080/1369118X.2015.1070889

Creswell, J. W. (2007). Qualitative inquiry \& research design: Choosing among five approaches (2nd ed.). SAGE publications, Inc.

Fraenkel, J. R., Wallen, N. E., \& Hyun, H. H. (2012). How to design and evaluate research in education. McGraw-Hill Companies, Inc. https://doi.org/10.1017/CB09781107415324.004

Georgiou, S. N., Stavrinides, P., \& Fousiani, K. (2013). Authoritarian parenting, power distance, and bullying propensity. International Journal of School and Educational Psychology, 1(3), 199-206. https://doi.org/10.1080/21683603.2013.806234

Hong, F.-Y., Lin, C.-C., Lin, T.-J., \& Huang, D.-H. (2019). The relationship among the social norms of college students, and their interpersonal relationships, smartphone use, and smartphone addiction. Behaviour \& Information Technology, 1-12. https://doi.org/10.1080/0144929X.2019.1699959

Husna, N., Normelani, E., \& Adyatma, S. (2017). Hubungan bermain games dengan motivasi belajar siswa sekolah menengah pertama (SMP) di Kecamatan Banjarmasin Barat. Jurnal Pendidikan Geografi, 4(3), 1-14.

Huver, R. M. E., Engels, R. C. M. E., \& Van, G. (2007). Parenting style and adolescent smoking cognitions and behaviour. Psychology and Health, 22(5), 575-593. https://doi.org/10.1080/14768320600976182

Iacolino, C., Lombardo, E. M. C., Cervellione, B., Mannino, G., \& Micieli, S. (2019). Internet addiction disorder: Internet gaming disorder in a nonclinical sample of Moba and Mmorpg videoplayers. World Futures, 1-27. https://doi.org/10.1080/02604027.2019.1654775

Jenny, S. E., Manning, R. D., Keiper, M. C., \& Olrich, T. W. (2016). Virtual(ly) athletes: Where esports fit within the definition of "sport." Quest, 1-18. https://doi.org/10.1080/00336297.2016.1144517

King, K. A., Vidourek, R. A., \& Merianos, A. L. (2016). Authoritarian parenting and youth depression: Results from a national study. Journal of Prevention and Intervention in the Community, 44(2), 130139. https://doi.org/10.1080/10852352.2016.1132870

Konok, V., Bunford, N., \& Miklósi, Á. (2019). Associations between child mobile use and digital parenting style in Hungarian families. Journal of Children and Media, 1-19. https://doi.org/10.1080/17482798.2019.1684332

Kveton, P., \& Jelinek, M. (2016). Parenting styles and their relation to videogame addiction. International Journal of Psychological and Behavioral Sciences, 10(6), 1961-1964.

Lau, E. Y. H., \& Power, T. G. (2019). Coparenting, Parenting Stress, and Authoritative Parenting among Hong Kong Chinese Mothers and Fathers. Parenting, 1-10. https://doi.org/10.1080/15295192.2019.1694831

Linda, L. H., Russell, M., \& Johnson, E. I. (2016). Parenting emerging adults who game excessively: parents' lived experiences. 2840(December). https://doi.org/10.1080/01612840.2016.1253808

Llorens, M. R. (2017). eSport gaming: The rise of a new sports practice. Sport, Ethics and Philosophy, 1-13. https://doi.org/10.1080/17511321.2017.1318947

Lu, H. J., \& Chang, L. (2013). Parenting and socialization of only children in urban China: An example of authoritative parenting. The Journal of Genetic Psychology: Research and Theory on Human Development, 174(3), 335-343. https://doi.org/10.1080/00221325.2012.681325

Luo, S., Liu, Y., \& Zhang, D. (2019). Socioeconomic status and young children's problem behaviours mediating effects of parenting style and psychological suzhi. Early Child Development and Care, $O(0)$, 1-11. https://doi.org/10.1080/03004430.2019.1608196

Maftei, A., \& Enea, V. (2020). Symptoms of Internet gaming disorder and parenting styles in Romanian adolescents. PSIHOLOGIJA, 53(3), 307-318.

Miguel, I., Valentim, J. P., \& Carugati, F. (2016). From social representations to action: Proximity and the relation between social representations of the development of intelligence and authoritative parenting style. Revista de Psicología Social / International Journal of Social Psychology, 1-29. https://doi.org/10.1080/02134748.2016.1152682

Miles, M. B., Huberman, A. M., \& Saldana, J. (2014). Qualitative data analysis: A methods sourcebook. SAGE Publications, Inc.

Morganna, R., Sumardi, \& Tarjana, S. S. (2020). Tertiary English students' attitudes towards intercultural language learning. Indonesian Journal of Applied Linguistics, 9(3), 657-665. https://doi.org/10.17509/ijal.v9i3.23216

Muñoz, J. M., Braza, P., Carreras, R., Braza, F., Azurmendi, A., Pascual-Sagastizábal, E., Cardas, J., \& SánchezMartín, J. R. (2017). Daycare center attendance buffers the effects of maternal authoritarian parenting style on physical aggression in children. Frontiers in Psychology, 8(MAR), 1-7. https://doi.org/10.3389/fpsyg.2017.00391

Nelissen, S., \& Bulck, J. Van Den. (2017). When digital natives instruct digital immigrants: active guidance of parental media use by children and conflict in the family. Information, Communication \& Society, 
1-13. https://doi.org/10.1080/1369118X.2017.1281993

Paulussen-hoogeboom, M. C., \& Stams, G. J. J. M. (2008). Between children's negative emotionality and problematic behavior in early childhood. The Journal of Genetic Psychology, 163(3), 209-226. https://doi.org/10.3200/GNTP.169.3.09-226

Putri, R. R. (2018). Berapa lama idealnya, waktu bermain untuk anak dalam sehari? https://www.klikdokter.com/info-sehat/read/3614714 /berapa-lama-idealnya-waktu-bermainuntuk-anak-dalam-sehari

Ren, H., Cheah, C. S. L., Sang, B., \& Liu, J. (2019). Maternal attribution and Chinese immigrant children's social skills: The mediating role of authoritative parenting practices. Parenting Science and Practice, 1-11. https://doi.org/10.1080/15295192.2019.1694834

Shumow, L., VandellL, D. L., \& Posner, J. K. (1998). Harsh, Firm, and Permissive Parenting in Low-Income Families. Journal of Family Issues, 19(5), 483-507. https://doi.org/10.1177/019251398019005001

Smith, C. E., Noh, J. Y., Rizzo, M. T., \& Harris, P. L. (2016). When and why parents prompt their children to apologize: the roles of transgression type and parenting style. Journal of Family Studies, 1-24. https://doi.org/10.1080/13229400.2016.1176588

Stephenson, M. T., Quick, B. L., \& Tschida, D. A. (2009). Authoritative parenting and drug-prevention practices: Implications for antidrug ads for parents. Health Communication, 17(3), 301-321. https://doi.org/10.1207/s15327027hc1703

Takeuchi, M. M., \& Takeuchi, S. A. (2008). Marriage \& family review authoritarian versus authoritative parenting styles: Application of the cost equalization principle. Marriage \& Family Review, 44(4). https://doi.org/10.1080/01494920802454090

Tu, K. M., Elmore-Staton, L., Buckhalt, J. A., \& El-Sheikh, M. (2018). The link between maternal sleep and permissive parenting during late adolescence. Journal of Sleep Research, 27(5), 1-8. https://doi.org/10.1111/jsr.12676

Uji, M., Sakamoto, A., Adachi, K., \& Kitamura, T. (2014). The impact of authoritative, authoritarian, and permissive parenting styles on children's later mental health in japan: Focusing on parent and child gender. Journal of Child and Family Studies, 23(2), 293-302. https://doi.org/10.1007/s10826-0139740-3

Vučković, S., Ručević, S., \& Ajduković, M. (2020). Parenting style and practices and children's externalizing behaviour problems: Mediating role of children's executive functions. European Journal of Developmental Psychology, 1-17. https://doi.org/10.1080/17405629.2020.1768067

Warsah, I. (2020a). Forgiveness viewed from positive psychology and Islam. Islamic Guidance and Counseling Journal, 3(2), 108-121. https://doi.org/10.25217/igcj.v3i2.878

Warsah, I. (2020b). Religious Educators: A Psychological Study of Qur'anic Verses regarding al-Rahmah. Al Quds, 4(2), 275-298. https://doi.org/10.29240/alquds.v4i2.1762

Warsah, I., Masduki, Y., Daheri, M., \& Morganna, R. (2019). Muslim minority in Yogyakarta: between social relationship and religious motivation. Qudus International Journal of Islamic Studies, 7(2), 1-32. https://doi.org/10.21043/qijis.v7i2.6873

Warsah, I., Morganna, R., Uyun, M., Hamengkubuwono, \& Afandi, M. (2021). The impact of collaborative learning on learners' critical thinking skills. International Journal of Instruction, 14(2), 443-460.

WHO. (2018). Clasification of Diseases (ICD). https://www.who.int/classifications /icd/en/

Wischerth, G. A., Mulvaney, M. K., Brackett, M. A., \& Perkins, D. (2016). The adverse influence of permissive parenting on personal growth and the mediating role of emotional intelligence. Journal of Genetic Psychology, 177(5), 185-189. https://doi.org/10.1080/00221325.2016.1224223

Yu, W., Cheah, C. S. L., \& Sun, S. (2015). The moderating role of English proficiency in the association between immigrant Chinese mothers' authoritative parenting and children's outcomes. The Journal of Genetic Psychology, 176(4), 272-279. https://doi.org/10.1080/00221325.2015.1022503

Zamani, E., Kheradmand, A., Cheshmi, M., Abedi, A., \& Hedayati, N. (2010). Comparing the social skills of students addicted to computer games with normal students. Journal of Addiction and Health, 2(3-4), 59-65. https://doi.org/10.1016/S0924-9338(12)74212-8 